\title{
A ?carcineretid crab from Lower Turonian (Cretaceous) black shales of Misburg, Hannover area (Germany)
}

\author{
Chrǐstian Neumann" ${ }^{1}$ \& John W.M. Jagt ${ }^{2}$ \\ ${ }^{1}$ Museum für Naturkunde, Humboldt Universität Berlin, Invalidenstrasse 43, D-10115 Berlin, Germany; \\ ${ }^{2}$ Natuurhistorisch Museum Maastricht, de Bosquetplein 6-7, P.O. Box 882, NL-6200 AW Maastricht, \\ the Netherlands
}

Keywords: Crustacea, Decapoda, Carcineretidae, Turonian, Germany

\begin{abstract}
Although poorly preserved and missing most, if not all, carapace features that would allow for a proper assignment at the generic level, we think a crab (Fig. 1) contained in the collections of the late Professor Gundolf Ernst warrants a short description, if only in view of its preservational style.
\end{abstract}

\section{Introduction}

The brief description is distilled from observations on the specimen in question made by Professor R.M. Feldmann (Kent State University, Kent, Ohio), during an earlier visit to the Humboldt Museum, and ourselves. Preservation is poor (Fig. 1), with detail lacking over most of the animal; it appears that the ventral surface is exposed, with the length and width of the venter being about equal, c. $26 \mathrm{~mm}$. It might represent a female with an ovoid telson, $13.7 \mathrm{~mm}$ wide, $10.7 \mathrm{~mm}$ long. Chelípeds are equal and robust, with propodus and fixed fingers at least 27 $\mathrm{mm}$ long, and the proximal portion of the hand missing. Upper and lower surfaces show granules or very small spines, and the fixed finger of the left claw has domed denticles that increase in size proximally. The merus of ?third pereiopod is $\mathbf{2 3 . 9}$ $\mathrm{mm}$ long, $5 \mathrm{~mm}$ wide proximally, $3.7 \mathrm{~mm}$ wide distally; merus of fourth pereiopod equal to third, dactylus lanceolate. Pereiopod 5 with merus 10.8 $\mathrm{mm}$ long, c. $4 \mathrm{~mm}$ wide; carpus, propodus, dactylus flabelliform. Carpus $7.5 \mathrm{~mm}$ long, $5.5 \mathrm{~mm}$ wide; propodus $12.5 \mathrm{~mm}$ long, $8.0 \mathrm{~mm}$ wide; dactylus $5.2 \mathrm{~mm}$ long, $2.9 \mathrm{~mm}$ wide.
The accompanying label states, "cf. Portunus holsatus Fabricius. Turonian Black shales; Hannoversche Portland Cement, Fabrik II. Turon; Sapropel-Lage, Misburg; leg. Schumacher 22.11.75. The specimen is in the G. Ernst Collection, formerly at the Freie Universität Berlin, now at the Museum für Naturkunde (Humboldt Universität, Berlin). The late Dr R. Förster appears to have checked the specimen (30 January 1976) cursorily, and noted: 'Portunus sp., Schwimmkrabbe, Unterseite' (= Portunus sp., swimming crab, lower side).

\section{Strata}

Exposed formerly at the disused Hannoversche Portland Cementfabrik AG (HPCF II) quarry, east of Misburg, topographical map TK 25, sheet 3625 Lehrte, co-ordinates R - 3559120, H - 5806320, situated in the Kronsberg syncline east of Hannover, were marls and limestones of Early Cenomanian (dixoni Zone) to the basal conica/papillosa Zone of Early Campanian age, with a major hiatus comprising the upper Middle Turonian to the uppermost Coniacian (Ernst et al., 1997; see also Wood \& Ernst, 1998).

The black shale succession across the Cenomanian-Turonian boundary has been the subject of detailed studies (for a review see Hilbrecht \& Dahmer, 1994). Black shales intercalate with white limestones (the so-called 'Schwarz-weisse Wechselfolge') and may be subdivided into a lower member (Upper Cenomanian), a middle or 'major' member (Lower Turonian) and an upper member (upper Lower Tu- 


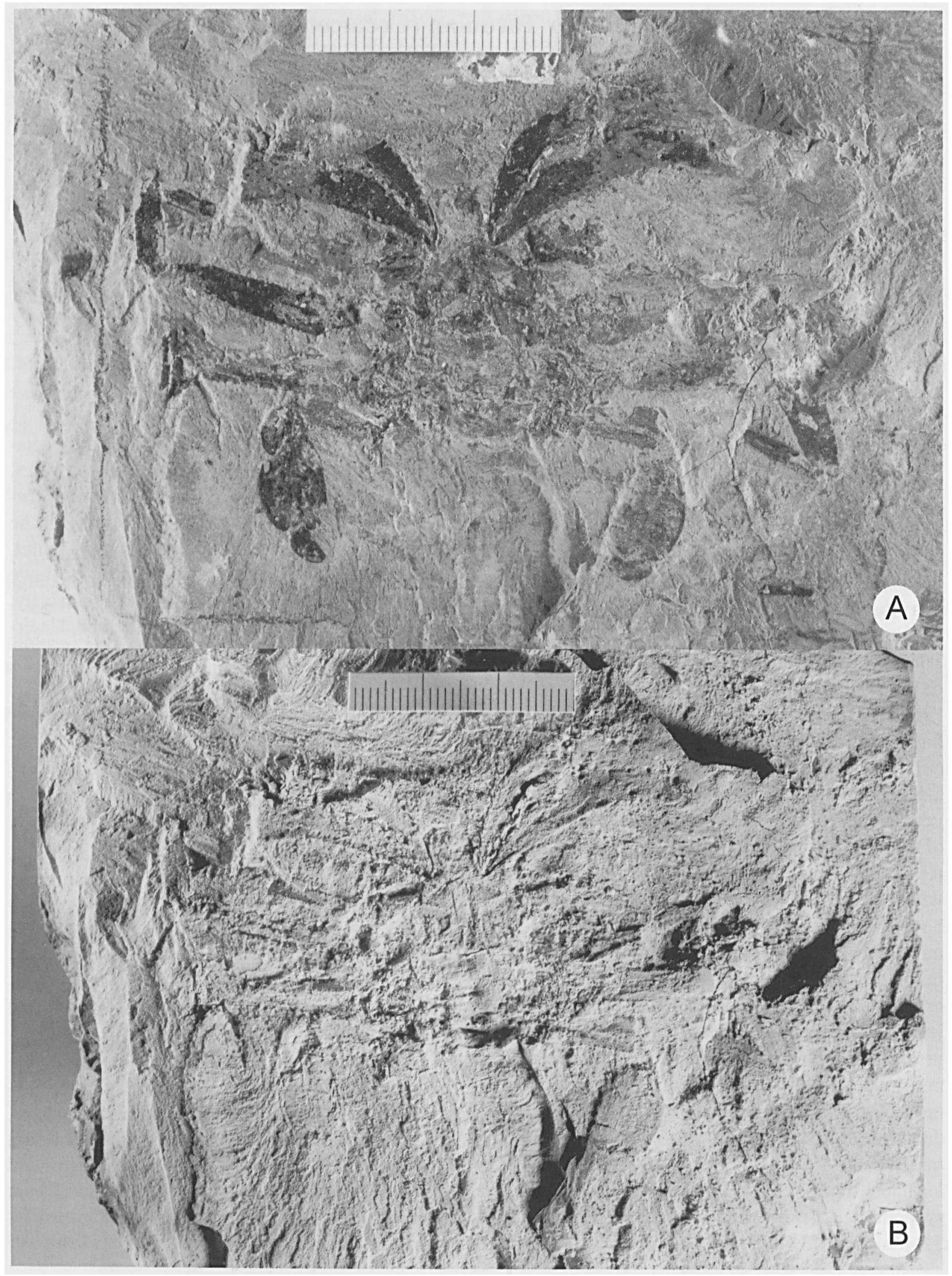


ronian), in which black shale beds become thinner. The laminated marls contain only up to to $1-3 \%$ Corg, which means they are not 'black shales' sensu stricto, and contain mainly inoceramid bivalves and ammonites, including Neocardioceras juddii, Thomelites sp. and abundant Sciponoceras, as well as well-preserved fish remains (Kriwet \& Gloy, 1995). Ernst et al. (1997, p. 81) referred to this find from one of the several black shale levels in the "Major Black Shale belt' of the Lower Turonian (see their fig. 56), interpreted as a basin facies.

\section{Results}

Although there are hardly any carapace features left that would have allowed us to place this find with more detail, carapace outline, pereiopod 5 with a flabelliform dactylus and cheliped size and structure would seem to favor assignment to the Carcineretidae. A lot has happened to members of this family in recent years, and more is undoubtedly to come. Feldmann \& Villamil (2002, p. 720) defined the Carcineretidae as follows: 'Carapace quadrangular, wider than long, bearing one or more prominent transverse ridges; fronto-orbital margin nearly equal to maximum carapace width; posterior margin narrow; propodi and dactyli of pereiopods 4 or 5 flattened into paddle-like structures'. Those authors accepted as true carcineretids only the genera Carcineretes, Branchiocarcinus, Mascaranada, Ophthalmoplax and Woodbinax, and reassigned others (Cancrixantho, Lithophylax, Longusorbis, Icriocarcinus, Withersella and Binkhorstia). With so few diagnostic features left we can only hint at a carcineretid affinity of the HPC II crab; possibly, the main interest of this find lies in the fact that it has paddle-shaped posterior legs, suggesting it to have been able to swim over short distances. More and better preserved material is needed to make a more definite assignment possible.

\section{Acknowledgements}

We thank Carola Radke (Museum für Naturkunde, Berlin) for preparation of photographs, and R.M. Feldmann (Kent State University, Kent, Ohio) and J.S.H. Collins (London) for sharing their views on the specimen with us.

\section{References}

Ernst G, Niebuhr B, Rehfeld U. 1997. HPCF II at Misburg. In: Mutterlose J, Wippich MGE \& Geisen M. (eds). Cretaceous depositional environments of NW Germany. Bochumer geol. u. geotechn. Arb. 46: 77-82.

Feldmann RM, Villamil T. 2002. A new carcineretid crab (Upper Turonian, Cretaceous) of Colombia., Jour. Paleo. 76: 718-724.

Hilbrecht H, Dahmer D. 1994. Sediment dynamics during the Cenomanian-Turonian (Cretaceous) oceanic anoxic event in northwestern Germany. Facies 30: 63-84.

Kriwet J, Gloy U. 1995. Zwei mesopelagische Raubfische (Actinopterygii: Euteleostei) aus dem Unterturon der Kronsberg-Mulde bei Hannover/Misburg (NW Deutschland). Berliner geowiss. Abh. E16: 335-356.

Wood CJ, Ernst G. 1998. Cenomanian-Turonian of Wunstorf. In: Mutterlose J, Bornemann A, Rauer S, Spaeth C \& Wood CJ (eds). Key localities of the northwest European Cretaceous. Bochumer geol. u. geotechn. Arb. 48: 62-73.

Received: 14 March 2003

\section{$\leftarrow$}

Fig. 1. Specifically indeterminate ?carcineretid; Hannoversche Portland Cement II, Misburg (Hannover area, Germany), Lower Turonian (black shale facies) A, uncoated, B, whitened with ammonium chloride sublimate prior to photography. Scale bar in mm. 